\title{
Semiotic alteration in translation. Othering, stereotyping and hybridization in contemporary translations from Arabic into Spanish and Catalan
}

\author{
Ovidi Carbonell i Cortés \\ Universidad de Salamanca \\ Universitat Politècnica de València
}

It is already widely recognized that 'foreignization' is a cover word which stands for many different processes of cultural translation, from a problematic literalism which tends to exoticism, to a welcome but rarely achieved 'othering' understood as an ethical act of respect for the other's specificity. Seen from a pragmatic perspective, what still needs to be assessed are the reasons behind a hypothetic threshold of acceptability and the extent of the unstable and risky space where source culture expectations are challenged as a result of the translator's management of socio-cultural biases. Starting from the assumption that cultural translation implies a metonymical move by which key textual elements stand as symbols representing the foreign culture, the proposed article will present a scheme of the pragmatic and semiotic processes at work in translations from Arabic into Spanish and Catalan. A review of recent Spanish translations of contemporary Arabic fiction and the muchacclaimed Catalan translation of the Qur'an will try to show that instances of hybridization and ambivalent readings occur foremost when semiotic categories are altered as a result of the familiarization of unexpected cultural referents. However, semiotic alteration only happens in the narrow margin allowed by the threshold of acceptability, which is the site of ambivalence.

\section{Migrant texts}

Translation resembles migration in many ways. Texts migrate in much the same way as physical lives are welcomed in or forced to migrate to other lands. The politics of translation deal with the same utopias, justifications, failures and sense of uneasiness, and if the migrant experience is basically a 'translational' experience, so rewriting or reading a foreign text implies some sort of relocation. The migrant filters and manages his experiences in different lands so that newness is either integrated or rejected, newness displacing, modifying or adding to original structures. So does translation.

Translation, as the migrant, reassesses reality through the looking-glass of identity. But how does it exactly manage identity? What bearings has such managing on the agency of the original?

The migrant who acquires a new culture may experience newness and its consequences diversely, ranging from a feeling of identification with 
certain traits (assimilation), to the displacement and forgetting of native modes of thought (deculturation), or a sense of alienating exoticism. As he or she becomes more familiar with and integrated into his or her new culture over the years, identification sets in, and exoticist criteria fade away. If circumstances are favourable, migrants may try not to sever their cultural and linguistic links with their homeland, so that, during their period of acculturation in their new setting, they experience a lesser sense of loss.

Unlike migrants, translated texts do not live immersed in a different culture which they gradually absorb. They are rather a product of the target culture, but they are products which take with them a possibility of giving way to the Other's voice, the Other's agency, the Other's illocutionary force. They are the migrant who performs specific functions in the wheels of the metropolitan machinery, but then also provides variations, departures and adjustments not easily noticed at first, but which prepare the ground for social change. And they may be written and used by migrants who bridge the language-culture gap. But how? Let us bear in mind Stuart Hall's words on cultural translation:

I use 'translation' in quotation marks too: translation as a continuous process of re-articulation and re-contextualization, without any notion of a primary origin. [...] I mean that whenever it enters a new cultural space, the terms change; and, exactly as you find in any re-articulation and disarticulation some elements remain the same, because there are clearly certain points, certain terms and concepts in common, but then there are also new elements which change the configuration. (Morley \& Chen 1996: 394)

Any cultural element, even within the same language, carries along a network of signifying relationships with the system in which it originated. This shapes the 'meaning' of such a cultural element, as well as all accompanying functions, distinctions and its contextual identity as belonging to such a system or subsystem. We may call these elements and their cognitive constructs emic insofar as they remain within their original system. Translation imbues cultural elements with a different set of relationships, identity marks and functions. Their interpretation by the new actors in the target culture is not emic anymore, but etic. Anthropologists and semioticians have long discussed how the interpreter's gaze tends towards a dispersal of the emic as a logico-empirical condition, so that the 'authentic' cannot be truly retrieved. In a similar way, all novelty implies a fundamental gap, but we can get around such a gap; or at least defer it, when novelty arises from a system of whose relationships we are knowledgeable, a system we belong to or at least feel a sense of identity with (as such knowledge always implies some sort of identification). Emic novelty is anticipated, even expected, and once it has been integrated, its condition of newness disappears.

The newness arising from a different culture has a different character altogether. According to Homi Bhabha, "the experience of colonialism is 
the problem of living in the "midst of the incomprehensible" (1994: 213). Unlike migrancy, colonialism tends to impose an interpretation in terms of the familiar. Installed in the etic perspective, the Other is a radical or absolute other only imaged through minute details that stand metonymically for the whole.

In order to resist the immense gap of incomprehensibility, colonialism enacts a fiction of translation. Translation is simulated through the phantasm of equivalence, and colonial subjects are made to speak as if for themselves - but their voice is mediated, at worst substituted, and more often than not transformed into cultural artefacts, commodified and marketed. The most extreme case might be Columbus's fiction of mutual intelligibility with the natives in the island of Guanahaní. Within hours after their first American contact, Columbus was able to write in his Journal precious data about their customs, creed and political conflict with neighbouring islanders. ${ }^{1}$ Another step is to strive to explain the foreign in terms of the familiar. Columbus resorted to an imaginary Orient mostly drawn from Marco Polo's Milione to give coherence to his discoveries in terms of his mental representations (Amodio 1993: ch.3). Bernal Díaz del Castillo's chronicle is influenced by chivalry books such as Amadís de Gaula, and Bernardino de Sahagún's Historia General projects classic imagery from Pliny and others to explain the Aztec culture. ${ }^{2}$ Many of these supposed similitudes had a practical purpose: legitimizing and devising the proper means to evangelize and control the colonized. Relying mostly on the familiar to locate the foreign Other, the colonizer adopts a perspective which, in Lacanian terms, is dominated by the Master's narrative: a perspective closed to the dialogic nature of discourse (Rodríguez Monroy 1999: 237).

Unlike the colonizer's, the migrant's interpretation highlights the transcultural and dialogic nature of signification. Rashid Nini was one such migrant. He made his way across the Strait and reached eastern Spain undocumented and clandestine, worked hard in the orange fields in southern Valencia, as a cook at a pizzeria in Benidorm, sojourned in Madrid, Paris and Brussels and finally returned to Morocco after having shared the experience of many fellow North-Africans, Eastern Europeans, Gypsy and non-Gypsy Spaniards as seasonal workers. In his novel Yawmiyyāt muhäjir sirrī translated as Diario de un ilegal - he presents a first-hand account of the ordeal of clandestine migrants in Spain. His acid, factual gaze challenges received stereotypes both sides of the Mediterranean: the idealized vision of Spain, the exoticist image of Morocco, the Spanish Reconquista celebrations, religious taboos and clichés from both sides.

There is hardly any exoticism in Nini's autobiographical Diary. It is, if at all, implicit in his caricature of European freak tourist habits in Benidorm, in his acute account of cultural presuppositions and in his rereading and counteracting, through his own cultural history, contexts which 
were supposed to emphasize, even celebrate, ideologies of racial and cultural exclusion. When attending a Valencian parade of "Moors and Christians", a festivity originally conceived to celebrate the Christian victory over Islam, whose actors are town citizens dressed as fanciful medieval Crusaders and Arabs, Nini recalls school images of Islamic epic characters such as ${ }^{\mathrm{c}} \mathrm{Al} \overline{\mathrm{l}}$, the Prophet Muhammad's companion, "drawn in a yellow cardboard above the blackboard, chopping off the monster's head with his forked sword" (Nini 1999: 31) (translation OCC.) or ${ }^{\mathrm{c}}$ Antara, the $5^{\text {th }} / 6^{\text {th }}$-century poet-knight. Nini, a cultured man who chose voluntarily to share the experience of thousands of fellow Moroccans, Algerians and the like, opposes the common flat rendering of history, a multi-dimensional and remarkable mosaic of sundry interpretations. In another passage (1999: 129), a line of cured ham legs or jamones hanging behind a bar counter brings him childhood memories of a lamb sacrificed and hung from a lemon-tree on the occasion of a Berber funeral.

The translators of Nini's novel, Gonzalo Fernández and Malika Embarek, are very conscious of the cultural limitations but also possibilities of translation, and they never act visibly as privileged interpreters of the foreign text. Their translation has no footnotes or glossaries; they control their intervention so that intratextual glosses are kept to a minimum. There is no preface, except for a concise biographical note. Even the back cover blurb consists of a quotation from the text. In this way, Nini's experience goes beyond the exoticist solipsism of the Spanish encounter with their Arab/Berber Other. Upon a re-reading from a different perspective, many Spanish referents are mirrored and seen in an entirely new light. The most radical of their options mark straightforwardly as foreign what traditionally has been assumed to be familiar. On page 175, we read:

Toledo. Viernes, una y media de la tarde. Me senté en una de las terrazas de Suqadawab. Enfrente está el Arco de la Sangre. No sé de dónde proviene ese nombre brutal, aunque sí sé al menos que en los siglos pasados la plaza de Suqadawab, en uno de cuyos cafés estoy sentado, era el lugar donde se dejaba el ganado antes de entrar a la ciudad. El nombre actual, escrito en el rótulo de mármol blanco, es Zocodover. (Nini/Fernández \& Embarek 2002: 175)

The original familiarizes the old Arab place name, which is brought closer to its Arabic readers emphasizing identity links by simply rendering it in Arabic. Instead of adapting the text to fit the well-known Spanish name, as any translator would have done, for example, with archaic Spanish place names in English texts such as Cordova, Monterey, or San Ysidro, the Spanish translation resorts to a kind of reversed exoticism aimed at its readers. The Arabic sūq ad-dawāb 'cattle market' is presented as the natural, quite mundane name, and its Spanish rendering, a simple matter of presentday contingency, thus dispelling all the exotic and epic imaginaries the name Zocodover carries to Spanish ears both in its etymological opacity and from its intertextual recreations in Spanish Christian literature. The 
translators provide no further explanation apart from the author's, and their only intervention is a surface phonetic adaptation, so that the famous Toledan square remains foreignized, a xenism. ${ }^{3}$

On another ocassion, Nini describes his visit to a Christian church:

\begin{abstract}
De vuelta a casa por la tarde, cuando paso delante de la iglesia, miro furtivamente, como quien no quiere la cosa, a través de la puerta pequeña que está abierta en medio de la puerta grande. El lugar está en silencio y no hay rastro de curas. Sólo la imagen de nuestro Señor Jesús en la cruz de madera. La iglesia tiene una puerta grande, con un cerrojo de hierro. Si la puerta pequeña está abierta, se puede ver el interior de la iglesia donde la imagen de Jesús está colgada por todas partes. Con las lágrimas eternamente petrificadas sobre su mejilla y con la herida sangrante debajo del costillar derecho, como en todas las imágenes que había visto antes. Me refiero a las que había visto en las enciclopedias que adornaban las estanterías en casa de mi tío en Casablanca. (Nini/Fernández \& Embarek 2002: 161-162)
\end{abstract}

Nini goes on describing the awe with which he contemplated Catholic imagery of demons, angels and Jesus Christ's Passion in his uncle's encyclopaedia, before shifting with no transition to his own present anxiety in the streets as an undocumented immigrant. By then, the Spanish reader has understood the cultural distance that this familiar iconography may cause to a non-catholic, but I would like to focus on the previous sentence "sólo la imagen de nuestro Señor Jesús en la cruz de madera". This is a close rendering of عـبسى سـيدنا وحده (Nini 1999: 137), but the result is unexpected insofar as the denomination of our Lord Jesus coincides in both cultures: here it becomes a token of nearness rather than separation. The average Spaniard may not be aware that Jesus ( $\left.{ }^{c} i s \grave{a}\right)$ is a key figure in Islam and the Qur'ân, and that the possessive (-nāa,nuestro) applies equally. Once the context of reception has changed, the possessive nuestro encompasses both cultures. It must be remarked that this is a consequence of the translators' decision not to capitalize the possessive; otherwise, Nuestro Señor might have been assimilated as a simple equivalent.

In the second reference to Jesus, the original text says السـيد صورة مكان كل فـي معلقـة المسـيح (Nini 1999: 37) which could have been rendered as "the image of the Lord Christ hung everywhere", but this would have prompted an incongruous Christian interpretation, and we may guess that it was for this reason that the translators opted for the more ambivalent la imagen de Jesús (in the final section I shall illustrate this problem with examples from the Qur'ān). These non-coercive strategies have prepared the ground for the final sentence: after a whole paragraph whose references apply equally to both identities, Muslim or Christian, the final remark depicts a cultural experience that Spanish readers do not experience as alien anymore. Their interpretation may be paraphrased thus: "both us and them share Jesus, but we have a different knowledge of Him". 


\section{Failures}

Exoticism implies novelty and the opaque attraction of the uncanny. Unlike the closing-up movement that we found in Nini's novel, exoticism underlines (and celebrates) untranslatability, the rift between cultures, and is centred overwhelmingly in the target culture. Media stereotyping caters for this rift, and its breaking down is the reason why tourists are so often disappointed: tourist brochures represent a foreign space already categorized, a spatially, politically, even chronologically circumscribed space, a foreign experience deemed non-coeval, expressed in primitivistic terms (Fabian 1983). Exoticist translations parallel these representations by means of controlled deviations which are not found in the original from a pragmatic perspective, and whose correlate is always a contrastive or antagonistic convention in the target culture.

For example, the Arabian Nights' language is assumed to be elaborated, polite, ornate and highly suggestive of the marvellous. When the Arabists Dolors Cinca and Margarida Castells, who two years earlier had won the prestigious Ciutat de Barcelona translation award for their comprehensive Catalan version, published in Spanish a much shorter translation of the oldest manuscript extant, various openly hostile reviews were published in two of the most widely circulated Spanish newspapers. What shocks most about this disparity is that, in fact, both translations followed similar translation procedures: the translators tried to bring the original closer to their readers preserving a pragmatic equivalence, avoiding literalism and dispensing with unnecessary exotic apparel not found in their sources.

The main reason behind such a failure was that their translation, in consonance with the colloquial, even indecorous tone of their Egyptian $13^{\text {th }}$ century source, provided pragmatic equivalents which clearly challenged their Spanish readers' expectations. One of the critics complained thus:

I would imagine that the translators have forceful reasons to render in this way the original, and let us suppose that what they want is to restore to the text its 'freshness', its popular and irreverent character. Unfortunately, what they get is a strange and sometimes terrible cultural transvestite, an operetta-like, plebeian Arabian Nights where the terror and melancholy of this collection of fantastic tales that have always fascinated us are diluted in a crude and often churlish humor. (Ibáñez 1999: 17)

It is apparent that these expectations relied on a controlled Otherness interpreted in terms of "a deviation from the norm, that is, our norm, and not the expression of another norm" (Egerer 2001: 26). Curiously enough, it had not produced such an effect on Catalan readers, presumably because Catalan literature did not really have a tradition of exoticist conventions, although this was sufficiently available to Catalans through Spanish works. 


\section{Metonymic constructions of the Other and the postcolonial project}

Egerer rightly pointed out the paradox that, "whereas the exotic is never at home (if it were, it wouldn't be exotic anymore), it is nevertheless closely linked to what we might label the "home culture"' (2001: 25). Exoticism results either from a fundamental ignorance of the Other, or a consciouslysought rhetorical effect which substitutes received images for more authorized knowledge.

The exotic element in the passages quoted does not reside in the foreignness of the scene, but consists precisely of its strong overtones of familiarity. The exotic resides in the lack of strangeness in what is being encountered, in the portrayal of the New World discovered as a re-discovery of a lost world, envisaged as a return to a state of innocence. (Egerer 2001: 24)

Egerer recognizes that exotic (re-)presentation implies a move towards "the discovery of 'a new location for old, nostalgic fictions", rather than the discovery of new lands or cultures (2001: 25). She then asks:

Problem: the way in which knowledge is constituted through the comprehension and incorporation of the other. Question: how can we formulate another kind of knowledge? One that does not assume the primacy of the same over the other. One that does not posit the other as absolute other, as something that escapes us, cannot be theorised. One that can imagine a nonhierarchical relationship between same and other. One that is non-coercive. (2001: 26)

These are the questions that postcolonial influence have brought into the terrain of translation. But there are no easy answers. Egerer welcomes the efforts by postcolonial theory to formulate "a new vocabulary of knowledge". It is, in her view, a new "awareness" that will reshape our knowledge of the other - that will lead, I would say, our translation - "not so much as the attempt to recover the 'original' story, as the desire to re-read historical texts, familiar texts, from the position of awareness" (2001: 28).

Egerer articulates her questioning around two philosophical positions: the Nietzschean negation of Otherness as it is reduced to familiarness to achieve mastery, and the Lévinasian ethical attempt to formulate an alternative understanding of knowledge by breaking the hegemony of the Same (Egerer 2001: 26). A text translated in such a way entails the adoption of a different perspective. Venuti has discussed the concepts of ethics of difference and minoritising translation in such a way; Vidal Claramonte has proposed a transversal ethics that would take into account

an ethics not circumscribed to a given culture nor to its specific government, but which at the same time takes into consideration the peculiarities of each society, having as its objective the analysis, in the first place, of the 
power/knowledge relationships which have constituted the source and target texts, and a subsequent analysis of what can be done in the face of the tentacles of the microphysics of power. (1998: 147)

I have pointed out the difficulties in attaining pragmatically the aims of these ethical projects (Carbonell 1997, 1999, forthcoming). In particular, I am suspicious of Venuti's whole theory - which is not so much a theory as a collection of perfectly valid suggestions drawn from sociolinguistics and cultural theory. I guess that such difficulties arise from the reproductive nature of translation: that it implies the actual production of a text, and the implementation of the above ethical instances must take into account the dialogical nature of the aesthetic-cultural reception context, in Bakhtinian terms (Rodriguez Monroy 1999: 249-255).

The translator may opt for rewriting the Other's experience along the stereotyped lines of the Same, or may challenge its expectations. This is the basic tenet of postcolonial translation: culture is always linked to identity, and provided that the vertiginous complexity of reality cannot be apprehended in its entirety, the postcolonial translator may redirect the metonymic gap towards the Same, instead of appropriating and reducing the other culture/ subject to exotic, domesticated metonymic fragments. So it is one's own culture that is othered/ foreignized.

Let us illustrate this point with a few examples. In the general management of foreignness, there are some options which are more prone to rely on the original agency than others.

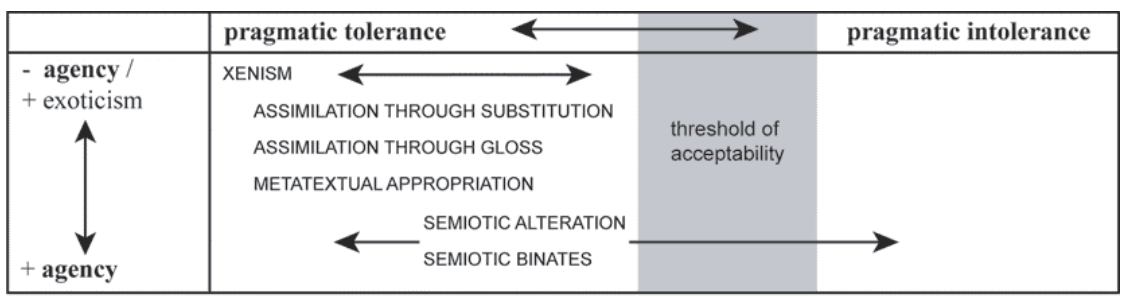

Figure 1: main postcolonial translation strategies

Xenisms illustrate the key difference between postcolonial literature in English (or any other hegemonic language), and postcolonial translation. The conservation of native terms or phrases is a resource often used by postcolonial authors to other the hegemonic language for its native readers to "represent his or her world to the colonizer (and others) in the metropolitan language, and at the same time to signal and emphasize a difference from it. In effect, the writer is saying 'I am using your language so that you will understand my world, but you will also know by the differences in the way I use it that you cannot share my experience" (Ashcroft et al. 2000: 137). Because of its metonymic effects, which reinforce stereotypes, opacity annuls agency when it is the hegemonic 
system which includes opaque elements from an exoticized system, but not when it is the subordinated or postcolonial system which provides them integrated into the postcolonial author's use of the metropolitan language.

Venuti's advocation of foreignization may easily fall into this misuse of the metonymic effect and it is definitely not recommended for all cultures that fall within the 'exotic' category and whose translation tradition has made of foreignization a basic tool of appropriation and exotic categorization. If, as Egerer and many others have pointed out, exoticism relies on the familiar, that is, on an expected exoticism, then a truly challenging translation strategy would be to produce unexpected turns that reveal the instability of the exotic discourse and its counterpart, the nonexoticism, 'naturalness' or even 'common-senseness' of the recipient culture. This is equal to the redefinition of expectations posited by Carol Maier (Maier 1995: 29).

Assimilations are the usual adaptation strategies where opaque elements are explained or replaced by others (see Franco 1996 for a lengthy explanation). Metatextual appropriation includes extratextual glosses or paratexts such as introductions, glossaries, marginal commentaries, etc. which re-present the text modifying or qualifying its setting (see also Waring 1995). It is kept to a minimum, for example, in Nini's translation.

What I call semiotic alteration is a consequence either of a recontextualization which prompts a palpable alteration in semiotic assumptions, or of the adjoining of conflicting readings which force a syncretic reading of the original. In both cases, the translator facilitates meanings which do not exist in the original; but, unlike exoticism, semiotic alteration tries to bridge the untranslatability gap. Nini's nuestro Señor Jesús is successful because it relies on the immense knowledge gap about Islam in Spanish culture, and forces a reassessment of both Jesus's role in Islam and Jesus's role in our Western cultural texts. So does SuqadawabZocodover. These are examples of a subversive familiarization of the foreign that must be distinguished from the quite different assimilation of the foreign to familiar exotic stereotypes. This subversion, semiotic alteration, modifies or annuls the stereotype usually projected onto the Other. Contemporary Arabic literature in Spanish translation, because of its academic, peripheral and postcolonial orientation, provides a few such examples - I have elsewhere talked about the uneasiness with which the Spanish reader accepts the term campiña 'countryside' applied to the Nile Delta, being as it is generally associated with green, luscious landscapes as in la campiña inglesa (Carbonell 2001).

Another translation strategy which implies a double movement of othering/identification is what I call semiotic binates. This is a type of gloss which is adjoined to the xenism or untranslated original without establishing any kind of cultural precedence, so that an effective dialogue takes place between their (often conflicting) meanings. 
Let us look at some examples taken from the Catalan translation of the Qur'ān by Professor Mikel de Epalza. Epalza is a pioneer in the application of this original strategy to a text whose antroponyms and scatological vocabulary are usually re-presented to Western readers in terms of the Christian tradition. Instead, Epalza introduces semiotic binates:

\author{
Déu, Al·là \\ Al-là, Déu \\ Issa, Jesús \\ l'infern Jahànnam \\ el paradís Adn [l’Edèn] \\ genis junnus
}

Such dialogue offers the possibility of a Catalan Islamic reading as well as presenting original proper names and place names as alternatives that resist their replacement by Christian reinterpretations or Western intertextual representations. Needless to say, both xenism and gloss experience transmutations, which I would call syncretic, but not hybrid (hybridization would be heretical both ways), following Jussawalla's acute review of both terms in postcoloniality.

It is perhaps paradoxical that these transmutations might be seen to emphasize the ${ }^{c} i j \bar{a} z$ or inimitability (and untranslatability) of the holy Qur'ān, while allowing each culture to retain and carry their specificities alongside translation. Do semiotic alterations defy or confirm the untranslatability of culture? Again, it must be stressed that, in reinscribing culture, translations cannot mean nor function in the same way as original works do. Translations are cues for resignifying, syncretic paths of acculturation; and this means an aperture to new modes of identity.

Fredric Jameson used Greimas's semiotic square for the purposes of cultural criticism to reveal "the limits of a specific ideological consciousness, [marking] the conceptual points beyond which that consciousness cannot go, and between which it is condemned to oscillate" (1981: 47). Following Jameson, James Clifford was in turn the first cultural critic to apply Greimas's semiotic square to postcolonial contexts. He took advantage of the square to explain the semiotic conceptualization of the artculture system, calling it "A Machine for Making Authenticity" (1988: 223). A similar semiotic square may also cast light on the machinery by which Others and Sames are constructed - and also how these very categories become ambivalent and even subversive in translation. 


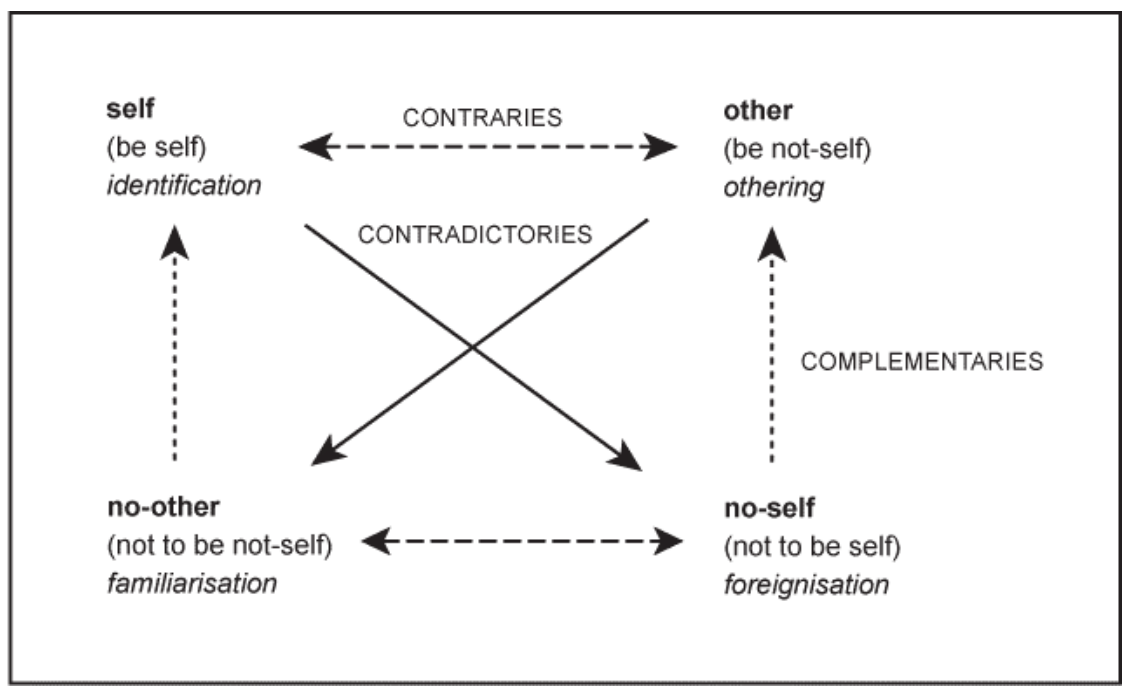

Figure 2: the semiotic construction of the Other

The initial binary opposition (self/other) generates four terms through a process of negation. Starting with the image of one's own cultural self, they define the identity of any linguistic item in discourse by means of the following performative categories: identification (establishing the ideological consciousness of the collective subject), othering (constructing a distinct subject through a politics of not-belonging), familiarization (discovering familiar traits in a subject previously established as other), and foreignization (discovering unfamiliar traits in a subject one had identified with).

None of these categories imply an ontology per se. They are, however, historically specific, contestable modalities of an ontology-oriented statement, inscribed in the structure of discourse (Clifford 1988: 223; Lozano et al. 1993: 78).

It may be noticed that identity-oriented translation strategies have a correlate with these four basic terms. Assimilation or domestication (in Venuti's terms) inscribes the translated text in the self-culture through seemingly perfect transparency. Xenisms or othering (in postcolonial terms) inscribe and classify the translated text in an inaccessible domain which is only suggested, enacting a metonymic gap (Ashcroft 2000: 37) in the recipient discourse. Exoticism or foreignization uses foreign-marked traits to establish the text as a prototypical other, and familiarization challenges exoticism adapting the other's discourse yet postponing an identification with it. Semiotic adaptations are familiarization strategies which make us discover 'familiar' traits in otherwise othered texts.

Whereas foreignization may be considered a form of exoticism by which a culture is marked as 'not-self' (by means of archaisms, uncommon rhetorical conventions, etc.), othering is a strategy chiefly used by post-colonial 
authors to counter colonial conceptualizations. We should bear in mind that a translated text cannot be classified as a 'pure other' without an absolute loss of intelligibility: a text is a 'pure other' only when not translated. Postcolonial authors sometimes try to abrogate the colonial idiom leaving untranslated words, phrases, sentences or even whole poems, speech interventions, etc. The other is thus supposed to remain Other, far from reader intelligibility, and thanks to this strategy the postcolonial author takes advantage of the reader's semiotic construction of him/her as 'other', resisting domestication as well as exoticist, reductionist foreignization. Of course, when translators supply a glossary or translation that is not found in the original, they may thwart in part the author's expectations.

Familiarization, for its part, is the destabilizing strategy that contradicts thinking of the other as Other. It moves us towards an identification, but this identification is not complete. The most effective familiarizing strategy is surely semiotic alteration. Although sparse, it prompts such a challenging re-evaluation of categories, that semiotically-altered items become metonymies for a syncretic space, thus opening the gap for the questioning of the whole semiotic conceptualization of self and other.

Identity-oriented translation strategies do not function in one single space. Rather, they may be located anywhere in the semantic zones between the horizontal and vertical axes, more or less close to the four main conceptual terms depending on the interpreter's intertextual and cognitive background. So, semiotic binates act on the zone between self and other, producing a syncretic movement. Assimilations and adaptations affect the area between the self and the familiar and their pragmatic effect is domestication. Foreignizing strategies may reach the terrain of the radical Other, but they tend to be nearer the conceptual area of the no-self (the inauthentic self). Finally, semiotic alterations act on the zone between an other closer to us (the inauthentic other) and the no-self, thus producing hybridizing movements.

With some reservations, I endorse the distinction between the hybrid and the syncretic established by Jussawalla (1995). My scheme seems to confirm such distinction: the syncretic allows for emic readings, while the hybrid seems to be installed in an etic perspective. The hybrid is disquieting, because it is based on negative postulates (the axis of subcontraries), but the syncretic juxtaposes a sense of belonging with another of not-belonging. While the syncretic aims at establishing a dialogue (re)creating its cultures, the hybrid is based on a severing of links. Or at least on the acknowledgement that our links do not suffice, and may be wrong. So this severance indeed produces a loss, which Homi Bhabha described as "a freedom from the essence of the self" (1994: 225).

Sometimes we call hybrids what amount only to ethnicist, postmodern mixtures rooted in the exotic imaginaries of the home culture. These are not real hybrids. Real hybrids provoke a semiotic re-evaluation of received stereotypes, and they at least inaugurate a disruption that calls into 
question the whole semiotic machinery of identity. Hybrids, because of this dis-location, this de-territorialization, are ambivalent.

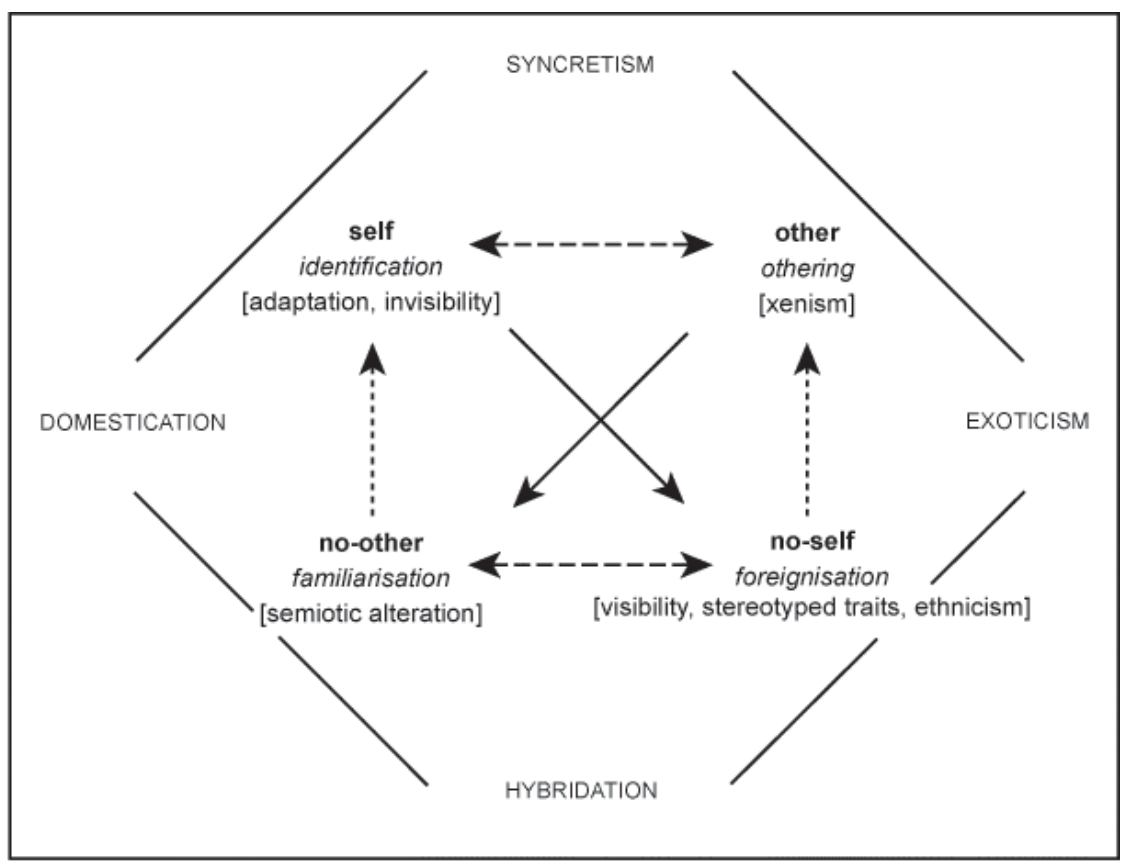

Figure 3: the translational management of the Other

Subversive postcolonial translations perform the role of the migrant the stranger - in a postcolonial society. Such texts effect a salutary task that dissipates the desperately self-assuring stereotyping of colonial exoticism, and they are also disturbing because they represent the ambivalence and paradoxical quality of translation:

Stereotyping, when effective, is taken as common sense, and when it is successful in this way it shuts down awareness of the contrary themes in common-sense thinking. Strangers open them up again, which is why they are discomfiting. They disturb because they do not quite fit. Stereotyping is a search for the comfort of precision, but strangers disrupt this search by representing the discomfort of imprecision. In doing so they may show people how they are incarcerated in the conventions they live by. (Pickering 2001: 219)

As strangers in the familiar site, postcolonial translated texts break down the stereotyping processes whose aim is to control the metonymic gap between cultures. Semiotically altered elements acquire a new meaning as signs of encounter, and this is how they may counter or even annul the signifying narrative of "cultural authority and its performative practices" (Bhabha 1994: 228). 
I wish to dedicate this paper to Africa Vidal-Claramonte, whose guidance opened up my mind and shaped my self, under Salamanca's clear skies.

\section{Bibliography}

\section{Primary Texts}

L'Alcorà. (2001). (tr. into Catalan by Mikel de Epalza in collaboration with Josep Forcadell \& Joan M. Perujo). Includes five scholarly articles on the Qur a-n. Barcelona: Proa.

Las Mil y Una Noches según el manuscrito más antiguo conocido. (1997). (tr. into Spanish by Dolors Cinca \& Margarida Castells). Barcelona: Destino.

Les Mil i una Nits. (1995). (tr. Into Catalan Dolors Cinca \& Margarita Castells). 3 vols. Barcelona: Proa, 1995.

Nini, Rachid (1999). Yawmiyyāt muhāŷir sirrī. Rabat: Manšurāt Wizārat Aš-šu'ūn At-taqāfiyya.

Nini, Rachid (2002). Diario de un ilegal. (tr. Malika Embarek \& Gonzalo Fernández). Madrid: Ediciones del Oriente y del Mediterráneo.

\section{Secondary Texts}

Álvarez, Román \& Ma Carmen África Vidal-Claramonte (eds) (1996). Translation, Power, Subversion. Clevedon: Multilingual Matters.

Amodio, Emanuele (1993). Formas de la alteridad. Construcción y difusión de la imagen del indio americano en Europa durante el primer siglo de la conquista de América. Quito: abya-yala.

Ashcroft, Bill (1989). "Is that the Congo? Language as metonymy in the postcolonial text." World Literature Written in English 29(2) (Autumn 1989), 3-10.

Ashcroft, Bill, Griffiths, Gareth \& Helen Tiffin (2000). Post-Colonial Studies: The Key Concepts. London/New York: Routledge.

Bhabha, Homi (1994). The Location of Culture. London/New York: Routledge.

Carbonell i Cortés, Ovidi (1997). Traducir al Otro. Cuenca: Universidad de Castilla-La Mancha/ Escuela de Traductores de Toledo.

Carbonell i Cortés, Ovidi (1999). Traducción y cultura. De la ideología al texto. Salamanca: Colegio de España.

Carbonell i Cortés, Ovidi (2001). "Identity in Translation." Actas del I Congreso de Traducción (CD Rom), Salamanca.

Carbonell i Cortés, Ovidi. (forthcoming). "La ética del traductor y la ética de la traductología." Ética y política de la traducción literaria. Grupo de Investigación Traducción, literatura y sociedad. Málaga: Universidad de Málaga.

Clifford, James (1988). The Predicament of Culture. Twentieth-Century Ethnography, Literature and Art. Cambridge, Mass.: Harvard UP.

Colón, Cristóbal ((1982) [1995]). Textos y documentos completos and Nuevas cartas. Consuelo Valera \& Juan Gil (eds) (1995). Madrid: Alianza.

Dingwaney, Anuradha \& Carol Maier (eds) (1995). Between Languages and Cultures: Translation and Cross-cultural Texts. Pittsburgh/London: University of Pittsburgh Press. 
Egerer, Claudia (2001). "Ambivalent Geographies. The exotic as domesticated Other." Third Text 55 (Summer 2001), 15-28.

Fabian, Johannes (1983). Time and the Other. How anthropology makes its object. New York: Columbia UP.

Franco, Josep (1996). "Culture-Specific Items in Translation.” R. Álvarez \& M.C.A. Vidal-Claramonte (eds) (1996). Translation, Power, Subversion. Clevedon: Multilingual Matters, 52-77.

Ibáñez, Andrés (1999). "El primer manuscrito de Las Noches." ABC Cultural (28 January 1999), 16-17.

Jameson, Fredric (1981). The Political Unconscious: Narrative as a socially symbolic act. Ithaca: Cornell UP.

Jussawalla, Feroza (1995). "Of The Satanic Verses' Mohajirs and Migrants. Hybridity vs. syncretism and indigenous aesthetics in postcoloniality." Third Text 32 (Autumn 1995), 85-93.

Lozano, Jorge, Peña-Marín, Cristina \& Gonzalo Abril (1993). Análisis del discurso. Hacia una semiótica de la interacción textual. Madrid: Cátedra.

Maier, Carol (1995). "Toward a Theoretical Practice of Cross-Cultural Translation.” Anuradha Dingwaney \& Carol Maier (eds) (1995). Between Languages and Cultures: Translation and Cross-cultural Texts. Pittsburgh/ London: University of Pittsburgh Press, 21-38.

Morley, David \& Kuan-Hsing Chen (eds) (1996). Stuart Hall. Critical dialogues in cultural studies. London/ New York: Routledge.

Pickering, Michael (2001). Stereotyping. The Politics of Representation. London/New York: Routledge.

Rodríguez Monroy, Amalia (1999). El saber del traductor. Hacia una ética de la interpretación. Barcelona: Montesinos.

Venuti, Lawrence (1998). The Scandals of Translation. Towards an ethics of difference. London/New York: Routledge.

Vidal Claramonte, $\mathrm{M}^{\mathrm{a}}$ Carmen África (1998). El futuro de la traducción. Últimas teorías, nuevas aplicaciones. Valencia: Institució Alfons el Magnànim.

Waring, Wendy (1995). “ 'Is This Your Book?' Wrapping postcolonial fiction for the global market." Canadian Review of Comparative Literature 22 (3/4), 455-65.

\footnotetext{
${ }^{1}$ Egerer (2001: 23): "Columbus' ease of communication with the natives would seem like a textbook example of side-stepping all complexities of cultural exchange". See also "La visión de las Indias", section 5 in Consuelo Valera's introduction to Columbus' Diary, where she explains the importance of the African experience in giving (supposed) coherence to the new world's landscape and its people.

${ }^{2}$ I thank this information to Victoria Ríos's ongoing $\mathrm{PhD}$ research on the cultural adaptation of Nahuatl culture by Bernardino de Sahagún, University of Salamanca.

${ }^{3}$ I take the concept xenism from terminology studies and extend its meaning to stand for any culture-specific word or phrase that remains phonetically unchanged in the target text, either maintaining its original phonemic transcription (qasīda), or ortographically adapted (qaseedah). A xenism is always sociolinguistically marked as foreign, and when such marking disappears because the source word or phrase has been integrated in the target language lexicon, then it is not a xenism proper, but a loanword (spaguetti - espaguetis; casida or alcázar in Spanish).
} 